\title{
USING HEAT TREATMENT OF BALLAST WATER FOR KILLING MARINE MICROORGANISMS
}

\author{
ACOMI, N[icoleta] \& GHITA, S[imona]
}

\begin{abstract}
By ships ballast water are transferred and discharged non-indigenous aquatic organisms into receiving waters. The Black Sea also was involved in such events as a source of organisms and as a colonized space too. To avoid that, the International Maritime Organization recommends treating the ballast water by means of different methods. One of them is based on heating ballast water in order to kill the organisms and microorganisms.

The paper present a system for recovering the heat from main engine for rise the temperature of ballast water and the impact of different stages of heating on the total number of cells. The samples were collected from Black Sea, analyzed using epifluorescent microscope and to estimate the total number of cells the CellC software was used.
\end{abstract}

Keywords: heating ballast water, marine microorganisms, epifluorescent microscopy

\section{INTRODUCTION}

Ships use ballast water to provide stability and maneuverability during a voyage. In this process, there are transferred millions of tons of ballast water from one place to another.

The impact of non-native species introduced via ships' ballast water has been documented (Ruiz et al., 1997; Gollasch, 2002; Hewitt et al., 2004) because of their negative disasters created in the economic field, in the marine environment and also in people health; over $\$ 5$ billion were losses due to invasion by the Zebra mussel in the Great Lakes in 1980 (Carlton, 2000 Tzankova, 2000), a comb jelly from U.S. Mnemiopsis leidyi was introduced in the Black Sea (1982) and preyed on fish larvae as well as their prey food, essentially wiping out the anchovy fishery there. In order to solve this problem the International Maritime Organization has elaborated an International Convention for the Control and Management of Ships' Ballast Water and Sediments (IMO, 2004). The Convention sets the number of viable organisms and microorganisms Table 1, allowed to be discharged with ballast water (IMO, 2005).

\begin{tabular}{|c|c|}
\hline Species & Concentration \\
\hline Toxicogenic Vibrio cholerae & Less than $1 \mathrm{cfu}$ per $100 \mathrm{ml}$ \\
\hline Escherichia coli & Less than $250 \mathrm{cfu}$ per $100 \mathrm{ml}$ \\
\hline Intestinal Enterococci & Less than $100 \mathrm{cfu}$ per $100 \mathrm{ml}$ \\
\hline
\end{tabular}

Tab.1. The indicator microbes for ballast water

The heat treatment of ballast water has been presented as a possible treatment method based on theoretical (Bolch and Hallegraeff, 1993; Hallegraeff et al., 1997; Mountfort et al., 1999) and laboratory trials (Rigby et al., 1999; Mountfort et al., 2001). Different methods of heating the ballast water on board vessels have been proposed (Rigby and Hallegraeff, 1994; Rigby et al., 1997; Mountfort et al., 2001; Quilez-Badia G. et al. 2008).

Most of the experiments until now were focused on different species of marine organisms (Bolch and Hallegraff, 1997; Montani et al.1995), table 2.

\begin{tabular}{|c|c|c|c|}
\hline Species & Temp. & Time & Source \\
\hline & ${ }^{\mathbf{0}} \mathbf{C}$ & $\mathbf{h m s}$ & \\
\hline G. catenatum & $35-37.5$ & $1-2 \mathrm{~h}$ & Hallegraeff et al. (1997) \\
\hline G. catenatum & $40-45$ & $30-90 \mathrm{~s}$ & Bolch and Hallegraeff (1993) \\
\hline Alexandrium Sp. & 45 & $3 \mathrm{~m}$ & Montani et al (1995) \\
\hline A. cattenella & 38 & $4 \mathrm{~h} 30 \mathrm{~m}$ & Hallegraeff et al. (1997) \\
\hline
\end{tabular}

Tab. 2. Lethal temperature for different species

We counted the total number of microorganism and the evolution at different stages of heating.

\section{BALLAST WATER TREATMENT BY HEATING}

Ballast water is heated by using the engine cooling system. This is a very efficient method because coolant water is necessary and would most likely be discharged into the ocean if it were not used to treat ballast water. Another benefit to this method is that there are no resulting chemical byproducts.

\subsection{The retrofitting of the ballast system}

Ballast water is heated by using the engine cooling system.

The first modification of the ballast system is to use as ballast the sea water that was used as a coolant agent for the main engine low temperature cooling system is usually discharged overboard. We use this water for filling the ballast tank with sea water at $25^{\circ} \mathrm{C}$ as result from the diagram.

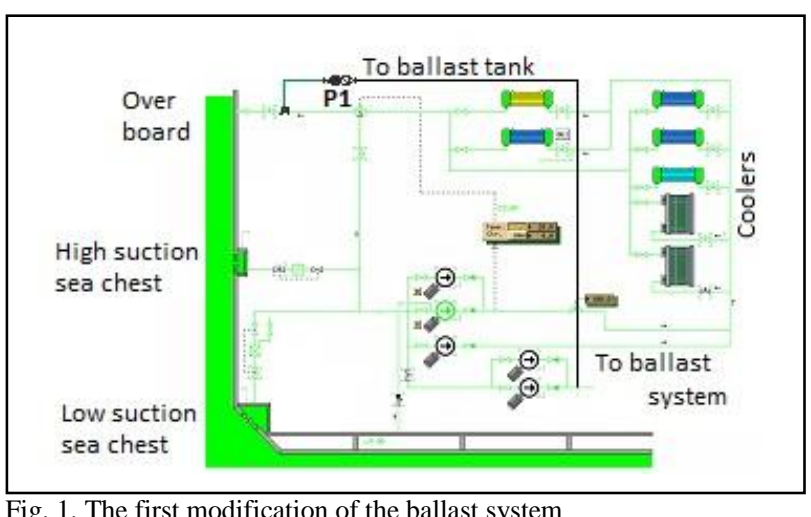


The temperature is not enough to kill the microorganism; so we will use a 20 percent of the flow from high temperature main engine cooling system at $80^{\circ} \mathrm{C}$ temperature. This flow rate is directed by a heat exchanger that will heat the sea water from the ballast tank.

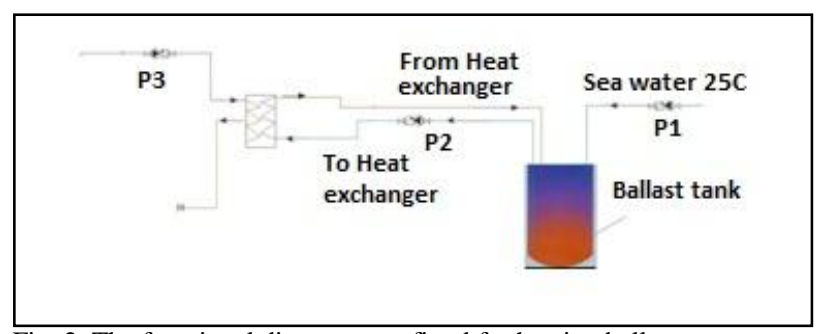

Fig. 2. The functional diagram retrofitted for heating ballast water

This is a very efficient method because coolant water is necessary and would most likely be discharged into the ocean if it were not used to treat ballast water. Another benefit to this method is that there are no resulting chemical byproducts.

The treatment method is limited by the amount of heat provided by the engines, so the amount of ballast water to be treated must be compared to the heat released by the engines. A number of factors need to be considered before using heat treatment on a specific ship or a particular voyage. The voyage must be long enough to allow water to reach the specified temperatures for the necessary amount of time.

\subsection{The methodology used for analyzing the samples}

The most used methods for estimate the viable/ death cells based on colorful substances are those screening the entire membrane of the cells. These are made visible by coloring with fluorine components.

Sample collection The sea water samples were collected from Black Sea area, latitude $44^{\circ} 07^{\prime} .5 \mathrm{~N}$ and longitude $028^{\circ} 41^{\prime} .7 \mathrm{E}$, in June 2012, 9 UTC, air temperature $27^{\circ} \mathrm{C}$ and sea water temperature $25^{\circ}$. The samples were screened in Marine Environment Laboratory from Constanta Maritime University. There were three samples 21 each, collected in bottles.

Fluorescence microscopy is based upon the concept that there are certain materials that emit energy which can be detected as a visible light. Each of these materials must be irradiated with a different specific light wavelength in order to cause an energy reaction in the form of light. The sample being used can either be treated with some fluorescing substances or it can be fluorescing on its original form. Fluorescence microscopy differs from most traditional techniques in that the visible light in the microscope eyepieces is not the original light emitted by the light source. The light seen is actually light that has fluoresced from the specimen itself. In order to receive such a response a high intensity light source must be used. This light is passed through a dichroic filter cube containing a fluorescence band pass excitation filter, which only allows specific wavelengths of light to pass and reach the fluorescence specimen. After the incident filtered light reaches the specimen, it is no longer used, and any amount reflecting back into the microscope objective to the dichroic mirror is refined by the emission filter. The specimen fluoresces and it is this fluorescing light that passes back through the fluorescence emission filter and goes to the microscope eyepieces to provide a bright and colorful fluorescence image of the specimen.

Epifluorescent microscope utilizes a $100 \mathrm{~W}$ mercury burner light source. The epifluorescence microscope features a ocular head; 4x, 10x, 40xR and 100xR (oil) planachromatic objectives; a blue (450-480 nm) /green $(510-550 \mathrm{~nm})$ dual band filter set; The filter sets provide superior performance in conjunction with a wide variety of most common fluorophores. The 40xR and 100xR objectives feature a retractable lens.

Samples were viewed immediately by epifluorescence microscopy (N-400FL, lamp Hg 100 W, type on the blue filter- $450-480 \mathrm{~nm}$ ) with immersion $100 \mathrm{X}$ objective and $10 \mathrm{X}$ eyepieces; AO staining (10 $\mu \mathrm{g} / \mathrm{mL})$; Measurement of 150 cells / filter.

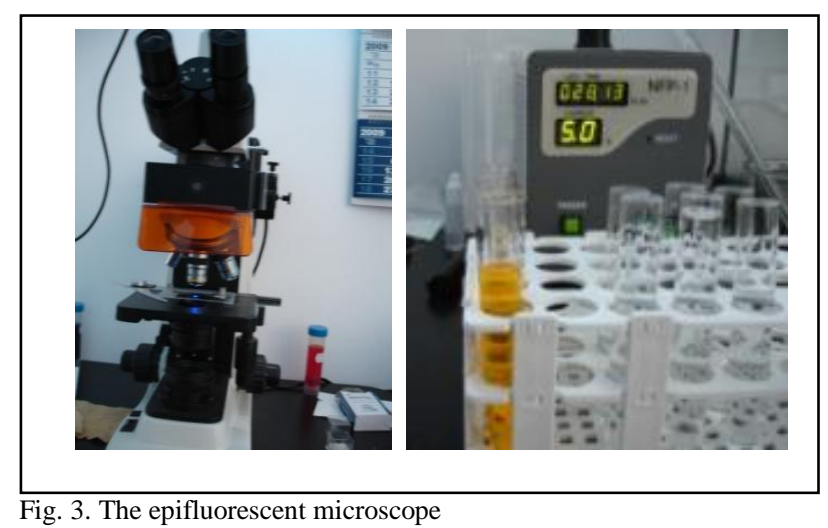

The main advantages of epifluorescent microscopy is that microorganism detection no need to much time, the analyses are made in real time and the fluorochromes is used diluted (a good cost to quality ratio). The disadvantages could be represented by the necessity of a special quartz light source.

Colorant epifluorescence SYBR-Green I (1000 $\mu \mathrm{g} / \mathrm{mL})$, is a small molecula that could penetrate the viable cells and also the death cells giving them a green fluorescent light. Reported previously for use with flow cytometry (Marie el al. 1997), SYBR Green I apears to be a viable tool for enumerating viruses and bacteria in seawater.

SYBER Green is an asimetric cyanine stain used for staining the nucleic acid in molecular biology. It has the advantage that is inexpensive and the manufacturer claims it to be much less carcinogenic (Noble T, 1998) than other typical nucleic acid stains.

For the total cell count we used two fluorochrome (SYBR Green I) in final concentration $10 \mu \mathrm{L} / \mathrm{mL}, 1$ : 100.000 (SYBR Green I), and staining time - 10 minute. The protocol work followed in agreement with (Lebaron et al., 2001; Sherr et al., 2001; Paul, 2001; Ardelean et al., 2009; Ghita et al., 2010; Ghita and Ardelean, 2010).

Other materials: filter membrane Millipore de $0.22 \mu \mathrm{m}$, Sudan black, Millipore glass filter holder. 


\subsection{The method used for counting the cells}

CellC Software can be used in automated analysis of microscopy images for counting the cells or for measurements of cell proprieties. We used it for counting the cells. The binarized results images are saved as JPG and the enumeration result ans statistic are saved as an Excel-ready CSV file.

For each filter we screen 20 fields, and using CellC: Software for quantification of labeled bacteria by automated image analysis based on MATLAB, we obtained the number of cells on analyzed filters.

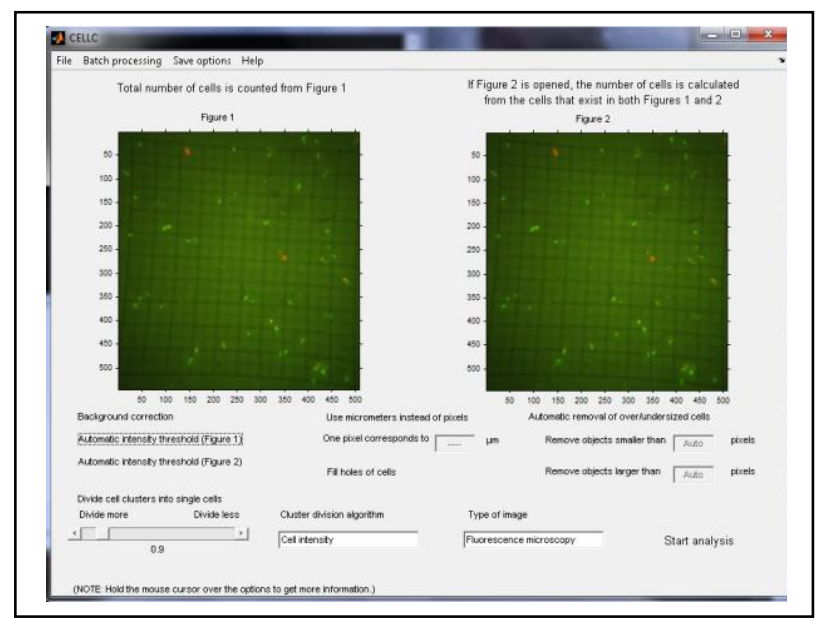

Fig. 4. The CellC software interface

In order to obtain accuracy results, the visualisation of the screened field is very important. It could be necessary to eliminate the "dirt". The imagines also should be taken with the same photo camera at the same rezolurion to avoid false final results.

\subsection{The experiment}

The sea water sample $10 \mathrm{ml}$ was mixed with $10 \mu \mathrm{L}$ SYBR Green I /ml sample, final concentration. The final concentration of SYBR Green I, used for counting the number of cells from each sample, was obtained with a dilution 1: 100.000 with de $10 \mu \mathrm{L}$ SYBR Green I $/ \mathrm{mL}$ sample.

After 5 minutes, the mixing (sample + stain) was filtered by a Millipore membrane, using a syringe and the holder. The filters used for the experiment were Millipore membrane filter polycarbonate $0,22 \mu \mathrm{m}, \mathrm{d}=$ $47 \mathrm{~mm}$, that retain most of the microorganisms. For blackening the filters we used Sudan black $0,1 \mathrm{~g}+30 \mathrm{~mL}$ ethanol $70 \%$ in order to minimize the background fluorescence.

After filtering process, supra stain was removed by washing with $10-20 \mathrm{ml}$ sterile water. Each filter was laiddown on a glass slide and analyzed using the Epifluorescent Microscope N-400FL, by blue filter (450-480 $\mathrm{nm}$ ) for current fluorochrome (SYBR Green I), having $100 \mathrm{~W}$ mercury burner light source, magnification 1000x (objective for immersion 100x, and grid ocular 10x), with one grid ocular micrometer, calibrated before.

We use the software CellC for counting (for automated image analysis, CellC being the main software used for processing multiple digital microscope images for count cells (http://www.cs.tut.fi/sgn/csb/cellc/).
The number of cells was transformed using the Fry, 1990 equation in number of cells per $\mathrm{ml}$, by a ocular grid calibrated for microscope type $\left(0,01 \mathrm{~mm}^{2}\right.$ aria).

$$
T=\frac{N A_{f}}{a V}
$$

where, $\mathrm{T}$ - number of cells per volume unit, $\mathrm{N}$ - number of cells per grid aria, $A_{f}$ - filtering aria,

$\mathrm{V}$ - volume of the filtered sample and a - grid aria.

For each filter was screened 20 fields (recommended by Gough \& Stahl, 2003).

\begin{tabular}{|c|c|c|c|c|c|c|c|c|c|}
\hline $\begin{array}{l}\text { Cell's } \\
\text { serial } \\
\text { number }\end{array}$ & $\begin{array}{l}\text { Eists in Figure } 2 \\
\text { (YES }=1, \mathrm{NO}=0 \text { ) }\end{array}$ & $\begin{array}{l}\text { Area of } \\
\text { cetll }\end{array}$ & $\begin{array}{l}\text { Approximate } \\
\text { volume }\end{array}$ & Length & Wisth & $\begin{array}{l}\text { Intensity } \\
\text { mean }\end{array}$ & $\begin{array}{l}\text { Intensity } \\
\text { maximum }\end{array}$ & Solidity & Compartress \\
\hline & & & 23.392 & 1.647 & 1.647 & & & 1 & \\
\hline 2 & & 16.693 & 23.392 & 1.647 & 1.647 & 71.5 & 83 & & 52.567 \\
\hline 3 & & 183.663 & $45.68 \mathrm{~B}$ & 20.587 & 20.587 & 71.2 & 81 & 1 & 42.054 \\
\hline 4 & & 1250.969 & $486.48 B$ & 45.292 & 45.292 & 812.667 & 133 & 0.86235 & 26.066 \\
\hline 5 & & $1 \quad 100.396$ & 78.949 & 24.705 & 24.705 & 633.333 & 84 & & 35.045 \\
\hline 6 & & $1 \quad 167.326$ & 187.139 & 3.294 & 3.294 & & 80 & 1 & 32.854 \\
\hline 7 & & 150.198 & 0.98666 & 12.352 & 12.352 & 653.333 & $6 \mathrm{~B}$ & 1 & 70.069 \\
\hline 8 & & 16.693 & 23.392 & 1.647 & 1.647 & 63.25 & 70 & 1 & 52.567 \\
\hline 9 & & 1284.454 & 486.488 & 45.292 & 45.292 & 860.588 & 136 & 0.94444 & 29.542 \\
\hline 10 & & 133.465 & 0.2924 & 0.8235 & 0.8235 & 66.5 & 67 & 1 & 105.134 \\
\hline 11 & & 1 1. 234.256 & 266.454 & 37.057 & 37.057 & 764.286 & 91 & 1 & 36.343 \\
\hline 12 & & 1 1. 234.256 & 365.506 & 41.175 & 41.175 & 90.5 & 133 & 1 & 29.438 \\
\hline 13 & & 133.465 & 0.2924 & 0.8235 & 0.8235 & 58.5 & 61 & 1 & 105.134 \\
\hline 14 & & 150.198 & 0.98686 & 12.352 & 12.352 & 63 & $6 B$ & 1 & 70.089 \\
\hline 15 & 1 & 1100.396 & 45.6Bв & 20.587 & 20.587 & 85.5 & 122 & 1 & 50.464 \\
\hline 16 & & 1200.791 & 365.506 & 41.175 & 41.175 & 81.5 & 106 & 1 & 25.232 \\
\hline 17 & & 150.198 & 0.98666 & 12.352 & 12.352 & 77 & 81 & 1 & 70.069 \\
\hline 18 & 1 & 183.663 & $45.68 \mathrm{~B}$ & 20.587 & 20.567 & 47.2 & 50 & 1 & 42.054 \\
\hline 19 & 1 & $\begin{array}{l}1 \\
1\end{array} 6.693$ & 23.392 & 1.647 & 1.647 & 58.25 & 62 & 1 & 52.567 \\
\hline 20 & & 1284.454 & $486.48 B$ & 45.292 & 45.292 & 907.059 & 168 & 1 & 29.542 \\
\hline 21 & 1 & $\begin{array}{l}1 \\
1\end{array}$ & 0.036551 & 0.41175 & 0.41175 & 61 & 61 & 1 & 210.268 \\
\hline 22 & 1 & $\begin{array}{l}133.465 \\
3.4\end{array}$ & 0.2924 & 0.8235 & 0.8235 & 70 & 73 & 1 & 105.134 \\
\hline 23 & 1 & 133.465 & 0.2924 & 0.8235 & 0.8235 & 69.5 & 79 & 1 & 105.134 \\
\hline 24 & 1 & 183.663 & 45.68в & 20.587 & 20.587 & 88.8 & 101 & 1 & 42.054 \\
\hline & 1 & $\begin{array}{ll}1 & 6.693\end{array}$ & 23.392 & 1.647 & 1.647 & 63 & 70 & 1 & 52.567 \\
\hline 26 & & 1167.326 & 187.139 & 3.294 & 3.294 & 78.1 & 119 & 1 & 32.854 \\
\hline & & 1 1 184.059 & 266.454 & 37.057 & 37.057 & 774.545 & 108 & 1 & 28.555 \\
\hline 28 & 1 & 1317.919 & 803.016 & 53.527 & 53.527 & 706.842 & 132 & 0.95 & 2.364 \\
\hline & 1 & $\begin{array}{l}133.465 \\
1\end{array}$ & 0.2924 & 0.8235 & 0.8235 & 79 & 81 & 1 & 105.134 \\
\hline 30 & 1 & 183.663 & $45.68 \mathrm{~B}$ & 20.587 & 20.587 & 63.2 & 65 & 1 & 42.054 \\
\hline 31 & 1 & 1. 133.861 & 125.368 & 28.822 & 28.822 & 86.75 & 120 & 1 & 34.329 \\
\hline & 1 & 1267.722 & 631.594 & 4.941 & 4.941 & 99.75 & 180 & 0.88869 & 23.363 \\
\hline 33 & 1 & 150.198 & 0.98686 & 12.352 & 12.352 & 646.667 & 72 & 1 & 70.089 \\
\hline 34 & 1 & 150.198 & 0.96666 & 12.352 & 12.352 & 533.333 & 56 & 1 & 70.089 \\
\hline 35 & 1 & 150.198 & 0.98666 & 12.352 & 12.352 & 646.667 & 71 & 1 & 70.089 \\
\hline ical & ans of column & $0^{n s} 11.665$ & 14.732 & 23.411 & 23.411 & 716.052 & 911.429 & 0.99045 & 57.851 \\
\hline
\end{tabular}

Fig. 5. CellC number

The fields were selected randomly in order to catch different cells density. The images were taken using digital photo camera Sony 7.2 megapixels.

\section{THE RESULTS}

We presented here the microorganism evolution when the ballast water was heated at $35^{\circ}, 40^{\circ} \mathrm{C}$ and $45^{\circ} \mathrm{C}$. We obtained the total number of viable cells in sea water, normal condition of temperature $25^{\circ} \mathrm{C}$, presented in the $2^{\text {nd }}$ column and the total number of viable cells after heating at $T_{i}$ temperature for different periods of time $t_{1}$, $t_{2}$ and $t_{3}$. We also mentioned the SD - standard deviation which shows us the difference between the screened samples for each field.

Sample no.1

\begin{tabular}{|c|c|c|c|c|}
\hline \multirow{2}{*}{$\begin{array}{l}\text { Total no. } \\
\text { of cells }\end{array}$} & \multirow{2}{*}{$\begin{array}{l}\text { Initial } \\
\text { cond. } \\
\mathrm{T}_{\mathrm{o}}=25^{\circ} \mathrm{C}\end{array}$} & \multicolumn{3}{|c|}{ Constant temperature $\mathrm{T}_{1}=35^{\circ} \mathrm{C}$} \\
\hline & & $\begin{array}{l}T_{1}-t_{1} \text { after } \\
12 \text { hours }\end{array}$ & $\begin{array}{l}\mathrm{T}_{1}-\mathrm{t}_{2} \text { after } \\
48 \text { hours }\end{array}$ & $\begin{array}{l}\mathrm{T}_{1}-\mathrm{t}_{3} \text { after } \\
96 \text { hours }\end{array}$ \\
\hline $\begin{array}{l}\text { media } \\
\times 10^{6}\end{array}$ & 12.03 & 6.56 & 3.51 & 2.16 \\
\hline$\pm \mathrm{SD}$ & 3.4 & 1.45 & 0.68 & 0.27 \\
\hline
\end{tabular}

Tab. 3. The number of cells after heating at $35^{\circ} \mathrm{C}$

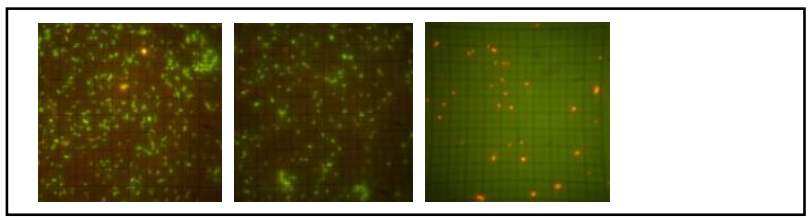

Fig. 5. The screened fields at $T_{o}$ and $T_{1}=35^{\circ} \mathrm{C}\left(t_{1}, t_{2}, t_{3}\right)$ 
Sample no. 2

\begin{tabular}{|c|c|c|c|c|}
\hline \multirow{2}{*}{$\begin{array}{l}\text { Total no. } \\
\text { of cells }\end{array}$} & \multirow{2}{*}{$\begin{array}{l}\text { Initial } \\
\text { cond. } \\
\mathrm{T}_{\mathrm{o}}=25^{\circ} \mathrm{C}\end{array}$} & \multicolumn{3}{|c|}{ Constant temperature $\mathrm{T}_{2}=40^{\circ} \mathrm{C}$} \\
\hline & & $\begin{array}{l}T_{2}-t_{1} \text { after } \\
12 \text { hours }\end{array}$ & $\begin{array}{l}\mathrm{T}_{2}-\mathrm{t}_{2} \text { after } \\
24 \text { hours }\end{array}$ & $\begin{array}{l}\mathrm{T}_{2}-\mathrm{t}_{3} \text { after } \\
36 \text { hours }\end{array}$ \\
\hline $\begin{array}{l}\text { media } \\
\times 10^{6}\end{array}$ & 10.84 & 5.57 & 2.79 & 1.23 \\
\hline$\pm \mathrm{SD}$ & 2.67 & 1.23 & 0.98 & 0.42 \\
\hline
\end{tabular}

Tab. 3. The number of cells after heating at $35^{\circ} \mathrm{C}$

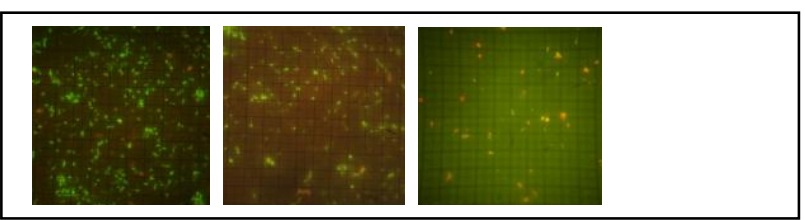

Fig. 6. The screened fields at $\mathrm{T}_{\mathrm{o}}$ and $\mathrm{T}_{1}=35^{\circ} \mathrm{C}\left(\mathrm{t}_{1}, \mathrm{t}_{2}, \mathrm{t}_{3}\right)$

Sample no. 3

\begin{tabular}{|c|c|c|c|c|}
\hline \multirow{2}{*}{$\begin{array}{l}\text { Total no. } \\
\text { of cells }\end{array}$} & \multirow{2}{*}{$\begin{array}{l}\text { Initial } \\
\text { cond. } \\
\mathrm{T}_{\mathrm{o}}=25^{\circ} \mathrm{C}\end{array}$} & \multicolumn{3}{|c|}{ Constant temperature $\mathrm{T}_{3}=45^{\circ} \mathrm{C}$} \\
\hline & & $\begin{array}{l}T_{3}-t_{1} \text { after } \\
1 \text { hour }\end{array}$ & $\begin{array}{l}\mathrm{T}_{3}-\mathrm{t}_{2} \text { after } \\
2 \text { hours }\end{array}$ & $\begin{array}{l}T_{3}-t_{3} \text { after } \\
4 \text { hours }\end{array}$ \\
\hline $\begin{array}{l}\text { media } \\
\times 10^{6}\end{array}$ & 11.67 & 3.12 & 1.06 & 0.64 \\
\hline$\pm \mathrm{SD}$ & 2.92 & 0.55 & 0.19 & 0.31 \\
\hline
\end{tabular}

Tab. 3. The number of cells after heating at $35^{\circ} \mathrm{C}$

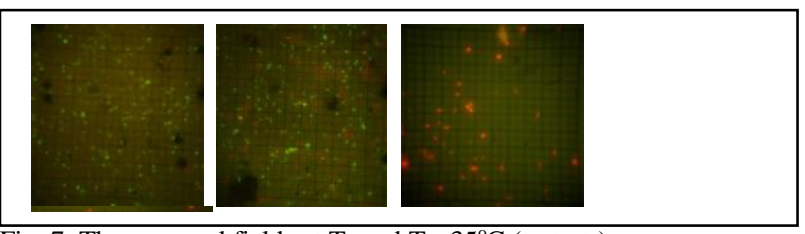

Fig. 7. The screened fields at $\mathrm{T}_{\mathrm{o}}$ and $\mathrm{T}_{1}=35^{\circ} \mathrm{C}\left(\mathrm{t}_{1}, \mathrm{t}_{2}, \mathrm{t}_{3}\right)$

\section{CONCLUSIONS}

The laborator experiments results shown that keeping ballast water for four days at $35^{\circ} \mathrm{C}$, kills $80 \%$ of the microorganism, one day and a half at $40^{\circ} \mathrm{C}$, kills $90 \%$. Those percents are inacceptable for treating ballast water in naval transport because International Maritime Organisation set rulles regarding the desinfection by the Convention for of ballast water management and Sediments. The eficacity in killing the microorganism is aproximatly $95 \%$ if we keep for four hours the temperature at $45^{\circ} \mathrm{C}$. This percent is a good one but the method should be applied on a large scale, for a ship and based on the results the International Maritime Organisation would certify the method.

For retrofitting the ballast water system we considered that only one single ballast tank is suitable for heating. So, after the treatment method was applied, the treated ballast water should be moved from this tank to another one. That way a new quantity of sea water would be filled in the same tank and the heating treatment would start again.

Because of this period of delay, the treatment method of ballast water by heating is suitable for those types of ships that have small quantities of ballast water to be treated, for example port-containers and general cargos, rather than the large ships like petroleum tanks that unload all the cargos once and need to fill most of the ballast tanks with sea water, almost at the same time.

This analyze was based on the total number of microorganisms and their evolution when the sea water was heated in stages; the future research activity of the authors will be based on identifying the species of microorganisms from sea water, sampled from Black Sea, and their evolution during the heating process.

On the other hands we will work for optimizing the costs for retrofitting the ballast water system in order to install the above mentioned heat exchanger.

\section{REFERENCES}

[1] Noble, T. R..; Fuhraman, J. A. (1998). Use of SYBR Green I for rapid epifluorescence counts of marine viruses and bacteria, InterResearch, Aquatic Microbial Ecology, Vol 14, pp 113-118

[2] Mane, D.; Partensky, F.; Jacquet, S.; Vaulot, D. (1997). Enumeration and cell-cycle analysis of natural populations of marine picoplankton by flow cytometry using the nucleic-acid stain SYBR green 1. Appl Environ Microbiol Vol. 63(1), pp 186193

[3] Quilez-Badia G. et al. (2008). On board short-time high temperature heat treatment of ballast water: A field trial under operational conditions, Marine Pollution Bulletin Vol. 56, pp 127-135, Elsevier, doi:10.1016

[4] Bolch, C.J.; Hallegraeff, G.M. (1993). Chemical and physical treatment options to kill toxic dinoflagellate cysts in ships' ballast water, Journal of Marine Environmental Engineering Vol. 1, pp 23-29

[5] Hallegraeff, G.M.; Valentine, J.P.; Marshall, J.A.; Bolch, C.J. (1997). Temperature tolerances of toxic dinoflagellate cysts: application to the treatment of ships' ballast water. Aquatic Ecology, Vol. 31, pp 47-52

[6] Rigby, G.; Hallegraeff, G.M.; Taylor, A. (2004). Ballast water heating offers a superior treatment option. Journal of Marine Environmental Engineering, Vol. 7, pp 217-230

[7] Hallegraeff, G.M. (1998). Transport of toxic dinoflagellates via ships' ballast water: bioeconomic risk assessment and efficacy of possible ballast water management strategies, Mar Ecol Prog Ser, Vol. 168, pp 297-309

[8] J. Selinummi, J. Seppälä, O. Yli-Harja, J.A. Puhakka, 2005, Software for quantification of labeled bacteria from digital microscope images by automated image analysis, BioTechniques, Vol. 39, pp 859-863

[9] Sherr, B.; Sherr, E.; P. del Giorgio (2001). Enumeration of Total and Highly Active Bacteria, Methods in Mycrobiology, Vol. 30, pp 129-159

[10] Ardelean, I.I.; Ghiţă, S.; Sarchizian, I. (2009). Epifluorescent method for quantification of planktonic marine prokaryotes, Proceedings of the $2^{\text {nd }}$ International Symposium New Research in Biotechnology serie F, pp 288-296

[11] Lebaron, P.; Servais, P.; Agogue, H.; Courties, C.; Joux, F. (2001). Does the high nucleic acid content of individual bacterial cells allow us to discriminate between active cells and inactive cells in aquatic systems. Appl. Environ. Microbiol Vol. 67:17751782

[12] Paul, J.H. (2001). Methods in Microbiology. Marine Microbiology. Academic Press, 30:666

[13] Ghiţă, S.; Ardelean, I.I. (2010). Correlation between direct viable count of Gram-negative bacteria and biological oxygen demand in marine microcosms polluted with gasoline, Study

[14] Kongsberg Maritime (2005) Operator's manual, Engine Room Simultors, ERS MAN B\&W 5L90MC-L11, Doc.no.: SO-1136-D

[15] http://www.cs.tut.fi/sgn/csb/cellc/ 